\title{
МОНГОЛ-ОРОСЫН 1912 ОНЫ НАЙРАМДЛЫН ГЭРЭЭ БА И.Я.КОРОСТОВЕЦ
}

O.Батсайхан

1912 оны 11 дүгээр сарын 3-нд байгуупсан Монгол Оросын Найрамдлын гэрээний чухам үнэн байдлыг тодруупж, уг гэрээний учир холбогдол, Монголын түүхэнд оруулсан түухэн үурэг, эл гэрээ байгуупахад Оросын Засгийн газрын бүрэн эрхт төлөөлөгч И.Я.Коростовецийн уүрэг хэр байсан талаар тодруулахад энэхуу өгуУппийн зорилго оршино.

Монгопчууд 1911 онд тусгаар тогтнопоо тунхаглан зарласан 1911 оны зун байгуулагдсан Түр Засгийн газраас Монголыг тусгаар болгож, төр засгийг төвхнүүпэх ажлын хүрээнд Монгоп упсын хаан ширээнд Богд гэгээн Жавзандамбыг залж, суулгах их ёслоп хийх өдрийг бүх Монгоп даяар зарласнаас гадна Хүрээнд суугаа Орос упсын консулд албан ёсоор мэдэгджээ. 1911 оны өвлийн тэргуүн сард Түр засгийн газраас Их Орос улсын ерөнхий консупд явуупсан бичигт: "энэ жип зуны цаг манай Хапхын дөрвөн аймгийн хан ван, гүн, опон засгууд шарын шашныг өрнөон дэлгэруүпэх ба упс төрөө бататгахыг бүгдээр санаа нийлж, зөвлөлдөн Богд гэгээнийг Монгол улсын хаанд өргөмжилж эрдэнийн сууринд запж ёспон мергөж, их төрийн ёсполыг гүйцэтгэх одрийг энэ цагаагчин гахай жилийн овлийн дунд сарын шинийн 9ний барс цагт тогтоосон учрыг Оросын эзэн хааны засгийн газар уламжипна уу" Хэмээжээ. ${ }^{1}$

Монгопчууд сайн одрийг сонгон хүпээж, Монголын төрөө тунхаглан зарлахад хэн хүнгүй бэлдэцгээсэн байна. Холынхоос нь хэмээвэл, "Халхын өмнө, умар хязгаарын ойр зэрэгцэн суусан Дариганга, Хөвсгөл нуурын Урианхайн бүгдийн дарга Сономдовдон, Хишигжаргал нараас тус тусын Богдын пүндэн зарпигийг чин үнэнхуугээр итгэн биширч соёлд багтахыг харьяа ардуудлаа зарлаад өршөөлийн дотор агуулах явдпыг хичээнгүйлэн гуйсугай"2 хэмээсэн бичгийг Хүрээний хэргийг шийтгэх газарт ируупсэн байв

Хапхын дөрвөн аймгийн хан, чуулганы дарга, жанжин, дэд чуупганы дарга, хэбэй, олон засаг ван, гүн, хутагт, хувилгаад, тайж түшмэд ардуудын төлөөлөгчид Хүрээнээ цугларан "Монголын төрийн орд, Дотоод, Гадаад, Цэрэг, Сан, Шүүх таван яамны байгуупалтыг урьдаар засацгаан бэлтгэхэд төв гэрүүдийг цөм монгол гэр үйлдэн"з бэпджээ.

Ийнхуч товпосон ёсоор Монголын шагаагчин гахай жипийн өвлийн дунд сарын шинийн 9 бөгөөд европ тооплын 1911 оны 12 дугаар сарын 29- ны өдрийн 12 цагт Монгол улсын хаан ширээнд Богд Жавзандамба хутагтыг өргөмжилснөөр төрийн их ёспол эхэпж байжээ. Мөн Богдын хатан, эрдэнэ сэцэн Цагаан Дара Дондогдупамыг улсын эхэд өргөмжипсөн байна. ${ }^{4}$

\footnotetext{
* О.Батсайхан - ОУСХ-гийн Орос судлалын секторын эрхлэгч, эрдэм шинжилгээний тэргуүпэх ажилтан, доктор (Sc.D), профессор
} 
Энэ бол Монгол улс Манжаас салж тусгаар улс болсноо тунхаглан зарласны илэрхийлэл байлаа.

\section{Найрамдлын гэрээ байгуулахын өмнөхөн уе}

Дөнгөж тусгаар тогтносон Монгопд өөрийн хувь заяаг Орос оронтой холбох үндэслэл байсан бол Орос орон ч гэсэн Монгопыг гойд сонирхох хангалттай үндэспэл байсан юм хэмээн И. Майский 1921 онд бичжээ.

Тухайлбал Монгол орон Орост юугаар хэрэгтэй байсан талаар хоёр зуйлийг хэлж болох юм, нэгдугээрт, эдийн засгийн хувьд, Монгоп орон мал болон мап аж ахуйн түүхийн эд Оросын зах зээлд нийлүүпэгч байхаас гадна ууп уурхай байгалийн баяпгийн эх сурвалж болж байсан юм. Хоёрдугаарт, Монгоп орон Оросын хувьд улс төрийн онцгой ач холбогдоптой байсан. Хятад энэ уед дотоодлоо хагаралтай байж, европийн соёлд дасан зохицох гэж зовж байгаа билээ. Дээр дурьдсан зүйлүүдэд үндэслэн Орос улсаас Монголын талаар баримтпах ерөнхий чиг шугамыг харж болох бөгөөд тэр нь Орос орны хувьд Монголын төрийн тусгаар тогтнолыг тодорхой хэмжээгээр хадгапах нь оншгой чухал байсан, Монгол орныг буфер маягаар барьж байх сонирхол Оросын төрд байсан хэмээн Майский үзэж байжээ. ${ }^{5}$

Хятадын эрхтэнүүд Оросын элчингийн хооронд монголын асуудлаар маргаан болж байх завсар Бээжин дэх Оросын элчингийн дэвшүүлсэн саналыг Оросын Гадаад явдпын яам нааштай хупээн авч, Орос Халхын хооронд байгуупж болох хэпэлцээрийн төспийг боловсруупан Засгийн газраараа хэлэлцэж, эзэн хаан хоёрдугаар Николайд танилцуупахад "Яаравчлах хэрэгтэй" хэмээн тэрээр цохжээ. Эзэн хааныхаа өгсөн зааврын дагуу Оросын Сайд нарын Зөвлөлийн тусгай хурапдаанаар 1912 оны 8 дугаар сарын 2-ны өдөр уг асуудлыг хэлэлцэж, Гадаад явдлын яамны сайдын саналаар Монголын асуудлаар Хятадтай явуулж буй хэлэлцээг тасалж, Хүрээтэй нууц хэлэлцээг эхлэх шийдвэр гаргажээ. ${ }^{6}$ Орос улсын Сайд нарын Зөвпөл 1912 оны 8 дугаар сарын 2-ны хуралдаанаар Монголтой байгуулах гэрээний асуудлыг "Хүрээний хутагт ба халхын ноёдтой байгуулах гэрээний тухай» гэсэн нэрийн дор авч хэлэлцэн гаргасан шийдвэртээ "Монголын асуудлаар азнах явдал улам бүр осолтой болсоор" байна гээд энэ байдnаaс гарах "сайн арга шийдвэр гэвэл Орос, Халхын хооронд дипломат гэрээ байгуулах явдал мөн гэж” заасан байна. Бэлтгэж байгаа гэрээг Монгоп улстай байгуупах гэрээ хэмээн нэрлэхгүйгээр зөвхөн “Хурээний хутагт ба халхын ноёдтой байгуулах гэрээ” гэж томьёолохын хамт гэрээгээр Монголын тунхаглан зарласан тусгаар тогтнолыг хүлээн зөвшөөрч бататгах бус тодорхойгүй, бүрхэгдүухэн "Халхын ёс журам" гэдгийг хадгалан байлгахыг Орос улс амлах, "Дотоод Монгол ба Баргаас Хүрээний засгийн газарт дагаар орох тухай зарлан тунхагласан зарим зүйлийг одоохондоо уг хэпэлцээрийн гадна орхих" зэрэг . үндэспэлүүдийг баримтпах чиглэлийг уг шийдвэрт тусгасан байна. ${ }^{7}$

Энэхуү шийдвэр нь Монголын тусгаар тогтнолыг шууд хүгээн зөвшөөрөхөөс зайлсхийсэн өнгө аястай боловч гэрээ байгуулах субьект нь "Орос ба Монгоп" гэсэн хоёр этгээд байх бөгөөд хэлэлцээнээс гарах баримт 
бичиг нь олон улсын хууль зүйн хэм хэмжээнд ямар нэгэн байдлаар нийцсэн дипломат гэрээ байх нь магад туп Монгопын хувьд олон упсын харилцааны талбарт гарах чухал ач холбогдолтой байх нь эргэлзээгуй хэрэг байлаа. Мэдээж Оросын эзэнт улс өөрийн ашиг сонирхлын асуудлыг урьдач болгож байсан хэдий ч монгопчуудын хувьд ийм замыг сонгох нь ашигтай байлаа. Үүнийг Монголын төрийн зүтгэлтнүуд сайтар ухаарч байсан юм. Орос улсын төрийн зуттэлтнууд, Гадаад яамны сайд Монголтой шууд харилцаж, хоёр орны хооронд хэлэлцээр байгуулах асуудлыг түргэвчилж эхэппээ.

Орос улс Монголтой шууд хэлэлцээр хийхээр нэгэнт шийдсэн туп даруй ажипдаа орж, энэ хэлэлџээг явуупах тусгай төлөөлөгчөөр туршлагатай дипломатч И.Я.Коростовецийг томипсон тухайгаа 1912 оны 8 дугаар сард Монголын Засгийн газарт мэдэгдсэн байна. Монгоп упсын Эзэн хаан Богд Жавзандамба хутагт тэргуүтэй Засгийн газар хоёр упсын хооронд Найрамдпын гэрээ байгуупах тухай умард хөршийн саналыг таатай хүпээн авч, эл хэлэлцээрийг явуупахаар тусгай элчин сайд Коростовецийг илгээсэнд Орос улсын хаан эзэнд талархаж буйгаа ипэрхийлжээ. ${ }^{8}$

Монголтой гэрээ байгуупах тапаар Оросын Засгийн газраас хийсэн дараагийн арга хэмжээ нь Оросын Гадаад явдлын яамнаас 1912 оны 8 дугаар сарын 23-нд Оросын бүрэн эрх барих төлөөлөгч И.Коростовешэд өгсөн заавар байлаа. Тэрхүу зааврын эхэнд: Монголын асуудлаар Орос улс Хятадтай хэлэпцэн тохироход чигпэсэн үйл ажиплагаа "ямар нэгэн мэдэгдэхүйц үр дүнд хүрсэнгуй", энэ нь хятадууд "Монголын тусгаар тогтнолыг хүчээр устгах" зорилгоор "Монголын ноёдын дунд яс хаях", Монголд "цэргийн ангиудыг явуулахаар бэлтгэх" зэрэг үйл ажилпагаатай холбоотой, үүнээс үндэспэн Орос улс Монгоп дахь байдал өөрчлөгдсөнийг үп харгалзагч хятадуудтай хэлэлцээ хийж болохгүй болпоо" гэж тэмдэглэжээ. ${ }^{9}$

Цааш нь бичихдээ: Оросын эзэн хааны Засгийн газар Хүрээний Засгийн газартай шууд харилцах замд орж түүнтэй гэрээ байгуупахаар шийдвэрлэлээ гээд Хаант Оросоос Монголд явуулах бодлогыг “манай хязгаартай хил дэрлэх энэ мужид цэргийн хүчтэй улс байгуупахгүй байхыг эрмэпзэх" явдал хэмээн тодорхойлоод "тавьсан зорилгоо хэрэгжүүпэхийн тупд 1. Халхад үндэсний эрхийг олгох, 2.Тэнд хятадын шэргүүдийг оруупахгүй байх, 3.Хапхыг хятадуудаар колоничлуулахгүй байх гэсэн гурван нөхцлийг хангахаар төлөвлөж байна"10 хэмээн мөн заавартаа дурьдсан байна.

Оросын худапдаа- үйпдвэрийн чигпэлийнхэн улс төрийн сонирхпоос илуу эдийн засгийн ашиг сонирхлоо урьтал болгож, Монголын түүхий эдийг дангаар ноёрхох бодпого агуулж байсан бөгөөд үүний улмаас Засгийн газраасаа Монгол дахь оросуудын худалдааны ипуу таатай нөхцөл, онцгой эрхийг хуупьчипж егөхийг шаардаж байсан юм. Энэ нь 1912 оны 10 дугаар сард Монгоп-Оросын хооронд байгуулсан Найрамдлын гэрээ, 1915 оны Хиагтын гэрээнд тусгалаа олсон гэдгийг тэмдэглэх нь зүйтэй юм. 


\section{1 оны дараах уеийн Монгопын опон упсын байдап}

Үнэн хэрэг дээрээ Оросын Монголын талаар баримталж байсан бодлого 1907, 1910, 1912 оны Орос- Японы Алс дорнод дахь нөлөөлпийн бүс хуваах тухай нууц хэлэлцээруудийн агуупгаар тодорхойлогдож байлаа. 1907 оны 7 дугаар сарын 30-нд байгуулсан Орос Японы улс төрийн гэрээ нь Алс Дорнод дахь их гүрнуүдийн шинэ харыцаг тусгаж, Манжуур, Солонгос, Монголыг нөлөөнийхээ хүрээнд хуЕаарипсан энэхуу баримт бичиг нь нээлттэй, нууц хоёр хэсгээс бүрдэж байсан бөгөөд нууш хэсгийн 3 дугаар зүйлд: "Гадаад Монгоп дахь Оросын тусгай сонирхлыг хүупээн зөвшөөрөхийн хамт эдгээр сонирхопд харшилж болзошгүй оропдлогоос түдгэлзэх үүрэг авсан" байна. ${ }^{11} 1910$ онд хоёр этгээд уг гэрээгээ дахин батапсан бипээ. 1912 оны 6 дугаар сарын 25-нд мөн асуудлаар Орос Япон хоёр улсын байгуулсан гурав дахь нууц гэрээний 2 дугаар зүйлд заахдаа: "Өвөр Монгол нь Бээжингийн уртраг (Гринвичээс зүүн тийш өргөрөг 116:27 )-ийн зүун баруун хоёр хэсэгт хуваагдана. Оросын эзэн хааны засгийн газар нь дээр дурьдсан уртрагаас зүүн тийш орших Өвөр Монголын хэсэг дэх Японы тусгай ашиг сонирхпыг зөрчихгуй үүргийг хүпээнэ. Японы эзэн хааны засгийн газар нь дурьдсан уртрагаас баруун тийш оршдог Өвөр Монголын хэсэгт Оросын тусгай ашиг сонирхлыг зөрчихгүй уүргийг хүпээнэ" гэсэн байна. ${ }^{12} 1911$ оны 8 дугаар сарын 2-нд А.А.Нератов В.Н.Коковцевт хандан: "Алс дорнодахины манай бодпогын үндэс нь Японтой байгуупсан хэд хэдэн хэлэпцээр бопон Манжуур цахь бий болсон үйл ажиппагааны нийтпэг нөхцөп байдпаас үүдэлтэй юм. Алс Дорнод дахь энэхуу амгалан тайван, аюупгүй байдлын гог: хүчин зүйлийг эрсдэлд оруулах нь болчимгүй хэрэг болох буй за"13 хэмээн бичсэн байдаг. 1912 оны 3 дугаар сард Орос улс Дундад Иргэн улсын засгийн газарт мэдтүгэй хэмээх нот бичиг илгээж: Дундад иргэн упс Хар мөрнөөс чэрэг томипж, Монгопд оруупбап Орос упс зүгээр харж суухгүй хэмээн мэдэгдэж байжээ. ${ }^{14} 1912$ оны 10 дугаар сард Монголтой Найрамдлын хэлэлцээр байгуулахдаа ч, 1913 оны 10 дугаар сарын 23 -нд Орос-Хятадын тунхагпапд гарын үсэг зурахдаа ч, 1915 оны Гурван этгээдийн Хиагтын хэлэлцээрийн туршид ч Оросын засгийн газар дээрх байр сууриа тууштай баримтапж байв.

\section{Орос Монгопын хооронд Найрамдпын гэрээ байгуулсан нь}

Харилцан тохирсон ёсоор Оросын Засгийн газрын бүрэн эрх барих төлөөлөгч Иван Коростовец 1912 оны 9 дүгээр сард Нийслэл Хүрээнд хурэлцэн иржээ. Оросын бүрэн эрх барих төлөөпөгч өөрийн Засгийн газрын шийдвэрийн ёсоор Монгоп упсыг автономит улс болгон хүпээн зөвшөөрүүгіэх үндсэн санаа бүхий хэпэпцээрийн боловсруулсан төсөлтэй ирж, түунийгээ Монголын төлөөлөгчид гардуулсан байна. Гэрээний төсөлтэй Монголын төлөөлөгчид танилцаад Мюнгол улсыг автономит болгох гол санааг үп зөвшөөрч өөрсдийн нэмэлт засварыг оруулсан хариу төспийг санал болгожээ. Монголын төлөөлөгчдийн боловсруулсан Хэлэлцээрийн төспийн үндсэн санаа нь: Нэгэнт 
тунхагпан зарпасан Монголын тусгаар тогтнолыг хэвээр хадгалан, түүнийг автономи болгон бууруупахгүй байх, Монгол улсад Өвөр Монгол, Баргыг оруулах, Монгол улсын Засгийн газрын төлөөлегчийг Оросын нийслэлд суулгах зэрэг байлаа. Хэлэлцээр хоёр талын оруулсан төспийг тойруулан нипээд маргаантай болж, гол нь хэлэлцээрийн үндсэн санааг өөр өөрсдийн байр сууринаас хадгалах үүднээс нилээд шируүн маргаан үүсгэж, заримдаа хэлэлцээ тасарч болох тийм байдалд хүртэл хүрч байжээ. Гэвч хугацаа сунжирч хэлэлцээр тасрах нь монголчуудад ашиггүй байх байсан туп монголын төлөөлөгчид тухайн үед их гүрэнтэй хийж буй чухал хэпэлцээрийн ач холбогдпыг зохих ёсоор тооцон үзэж, Монголын тухайн үеийн дотоод гадаад нөхцөл байдал, энэхуу хэлэлцээрээр олдож болох бопомжийг харгалзан цаашид Орос улсад төрийн төлөөлөгчид илгээх, дэлхийн упсуудад хандан дэмжлэг эрэх зэрэг нааштай алхам хийж болох төлөвт найдан зохих буупт хийсэн байна. Оросын төлөөлөгч ч гэсэн зарим зүйл дээр буулт хийж, "Гадаад Монгоп" гэсэн томьёоппоос "гадаад" гэсэн үгийг хасч, өргөн утгаар ойлгож болох “Монголия" гэсэн үгийг орос эхэд, "Монгол упс" гэсэн томьёолпыг монгол эхэл хэрэгпэхийг зөвшөөрч, бас "автономия" гэсэн грек гараптай франц үгийг монгол эхэд "өөртөө тогтнож", "өөрөө эзэрхэх" ёс журам хэмээн хөрвуүпэхийг үп татгапзахаар болжээ.

Ийнхүу хоёр талаас буулт хийсний дүнд 1912 оны 11 дугээр сарын 3-ны өдөр Оросын Засгийн газрын бүрэн эрхт төлөөлөгч Иван Коростовец Монголын Ерөнхий сайд Сайн ноён хан Намнансүрэн болон түуний Засгийн газрын 5 сайдтай Нийспэп Хүрээнд Найрамдлын гэрээ байгуулан, шинэ тутам байгуупагдсан Монгол улс Орос упсын харипцаа ямар байхыг тодорхойлсон юм.

Гэрээний оршилд монгопчууд Монголын нутаг дэвсгэрээс хятадын захиргаа ба цэргийг зайлуупсан, Богд Жавзандамба хутагтыг Монголын ард түмний хаанаар өргөмжилсөн, Монгол Хятадын урьдын харилцаа нэгэнт тасарсан зэрэг байдал болон Орос Монгоп хоёр улс эртнээс найрамдалтай байсан хийгээд орос монголын хооронд эдийн засаг, арилжаа өргөжиж, худалдааны журам тогтоох шаардлага гарсан зэргийг харгалзан гэрээ байгуупж буйг дурьджээ. Хэпэлцээрийн нэгаүгээр зүйлд: Оросын эзэн хааны Засгийн газар Монгоп упсад "өөрөө тогтнож, өөрөө эзэрхэх" ёс журмаа хадгалан сахих, мөн туүнчпэн “өорийн нутаг дэвсгэрт хятад цэрэг" ба "нуудлийн иргэдийг үл оруупан", "өөрийн упсын цэрэг байгуупах" эрхийг эдлэхэд цөм тусапна, Харин гэрээний монгоп эхэд энд дурьдсан дээр хоёр талын засгийн газрыг харипцан хүпээн зөвшөөрсөн гэсэн санаа туссан байгаа юм. Гэрээний хоёрдугаар зүйлд: Монгол уисын эзэн хаан ба Монгоп упсын засгийн газар өөрийн эзэмшип газарт Оросын харьяат нар ба Оросын худалдаанд хэлэлцээрт хавсаргасан Протоколд жагсаан заасан онц эрхийг (эрх ба давуу тапыг) хуучин ёсоор опгон хэрэгжуүлнэ Монголц Оросын харьяат нарт опгосноос ипүу эрхийг гадаад бусад орны харьяат нарт үл олгоно. Гуравдугаар зүйлд: хэрэв Монгол улсын засгийн газар хятад ба гадаад бусад упстай тусдаа гэрээ байгуупах хэрэгтэй гэж үзвэл шинэ гэрээгээр энэхуү хэлэлцээр ба хавсаргасан протоколд заасан 
зүйлүудийг Оросын эзэн хааны Засгийн газартай урьдаар зөвлөлдехгүйгээр зөрчих буюу өөрчипж үп болно. Дөрөвдүгээр зуйлд: Хэлэлцээр үсэг зурсан өдрөөс хүчин төгөлдөр болно гэсэн зааптууд оржээ. ${ }^{15}$

Эл гэрээний хавсралт протокол нь Монгол дахь Оросын худалдааны эрхийг давуу байдлаар хуульчилж өгсөн юм. Эп гэрээгээр Оросын эдийн засгийн давуу талыг дараах байдлаар тодорхойлсон байна. Тухайлбап, Орос упсын иргэд Монголын аль ч нутагт худапдаа эрхпэх, чөлөөтэй зорчих, үйлдвэр, үйлчилгээ гээд боломжтой бүх төрлийн бизнес явуулах, эзэмшил харгалзахгүйгээр гэрээ контракт байгуупах, гаапь татваргүйгээр Монголоос бараа гадаадад гаргах, гадаадаас оруулж ирэх, хувийн өмчийг чөлөөтэй хөгжүүлэх, Оросын санхуу, зээлийн байгууппагууд өөрийн сапбараа Монголд нээн ажилпуупах зэрэг эрхүудийг оросууд дангаар эдиэх болсон юм.

Оросын бүрэн эрхт төлөөлөгч Иван Яковлевич Коростовец Хүрээнд зорчсон тухай одрийн тэмдэгпэпдээ ${ }^{16}$ болон "Чингис хаанаас Зовполийн засагт Бүгд Найрамдах упс хүртэл" хэмээх номондоо Орос Монголын хооронд гэрээ хэрхэн байгуупсан тухай сонирхоптой дурсамж үпдээсэн буй. Тэрээр анх Монголын засгийн газрын ноёдуудтай уупзсан тапаар өгүүпэхдээ: "Консупын газар болсон хэлэлцээрийн эхний хуралдаанд эрх баригч ноёдууд бүгд ирсэн ба тухайлбал, Сайн ноён хан, Гадаад хэргийн сайд Ханд ван, Дотоод хэргийн сайд Да пам, Сангийн яамны сайд Түшээт хан, Шүүх яамны сайд Эрдэнэ ван Намсрай, Цэргийн сайд Далай ван нар байв. 1911 онд Петербургт очсон төлөөлөгчид болох Да пам, Ханд ван нарын тухай урьд ярьсан бипээ. Засагт ханыг нас барсаны дараа. Сайн ноён хан саяхан сайд болсон.Ноёдууд гоёлын хүрэм өмсч, бупган малгай тавьж, мориор ирцгээв. Тэдний бараа бологч олон тооны туспагчид нар хашаа үүдэнд ирцгээсэн байв.

Хурапдаанд манай тапаас надаас гадна, Ерөнхий консуп Пюба, Попов, Эльтеков болон консулын газрын орчуулагч буриад Церемпипов нар оропцов. Дараа нь энэ буриадаас нэг бус удаа би дэмжлэг авч байв. Тэрбээр Хутагтын ордонд ойр дотно байв. ${ }^{1 ?}$

Монгопд үргэлж нөхөрсөг хандаж ирсэн Орос орон ба Цагаан хаан Хятадаас сапсаны дараа учирч буй бэрхшээлийг мэдээд та бүхэнд туспахаар шийдвэрлэсэн юм хэмээн би мэдэгдэв. Хэрэв монголчууд бидэнтэй Монгол Оросын хэпхээ хопбоог бэхжүүпэх, Монголд өөрийнхөө автономийн төлөө тэмцэх болопцоо олгосон тийм хэпэлцээр байгуулвал Орос орны зорипт биепэхэд хөнгөн байх болно. Бээжинд элчин сайдаар байхдаа монголын хэрэгтэй ойр танилцаж байсан болохоор намайг хэпэпцээр хийх төлөөлөгчөөр томилсон юм.

Ноёдын өмнөөс нүшгэн топгойтой (бусад нь гэзэгтэй байв), шируүн харцгай пам Да лам үг хэлэв. Тэрбээр монгопчууд Орос улстай хэлэлцээр байгуулахад бэлэн байна, гэхдээ юуны өмнө Хятадтай харипцах харипцаанд хэрхэн нөлөөлөх талаар тодруупахыг хүсэж байна. Хятадууд бас хэпэпцээр хийхийг санал болгоод буй, хэлэпцээр хийлгэхээр монгоп ноён Наянтыг ирүүлэхийг хүсэж 
байна. Орос улсын цаашдын апхмуудыг хүпээзнэж, Монголын Засгийн газар Наянтыг хүпээн авахаас одоохондоо татгалзаад байгаа, Монголын Засгийн газар Гадаад Монголын нэгтгэх төдийгүй Дотоод Монголыг ч бас нэгтгэхийг эрмэлзэж байна.

Надад зөвхөн Халхын тухай п хэлэлцээр хийхийг даалгасан бөгөөд Дотоод Монголын асуудпыг одоохондоо босгон тавихгүй байсан нь дээр хэмээн би тайлбарлав. Хятадын тухайд тэдний монголчуудтай хийх хэлэлцээр бол тусгаар тогтнолыг тань солихтой адилхан болж магад. Бид хоёр талын ашиг тусын тулд монгопчуудтай ойртохыг хүсэж байна. Учир нь Монгол нь буфер- упсын хувьд манай хип дээр хятадын нэвтрэн орохын эсрэг түшиг тупгуур болж болох юм хэмээн бид үзэж байгаа юм. Бидний энэ апхам нь Бээжингийн засгийн газрын үйл ажиппагаанаас уүдэптэй бөгөөд бидний саналыг хүлээн авч ашиглах нь монголчудаас хамаарах болно.

Дуугүй сууж байсан Сайн ноён хан хариупахдаа монголчууд бид даван туупж буй энэ уеийн чухал хэмээхийг мэдэрч байна. Таны үг болон хэпэлцээрийн төслийн талаар Богд хутагтад шууд айлтгах болно хэмээснээр бидний эхний уулзалт өндерлөв ${ }^{18 "}$ хэмээсэн байна.

И.Я.Коростовец Орос Монголын гэрээ байгуупсан тэр өдөр чухам юу болсон талаар юу хэмээн тэмдэглэж үлдээсэн нэн сонирхоптой юм. Тэрбээр өгуүлэхдээ: "Аравдугаар сарын 21-нд гэрээ байгуупах явдал болов. ЭнэхуУ түүхэн үйл явдал хэрхэн болсон талаар одоо огүулье. Бид тэднийг ирэхээ больсон байх хэмээн бодож байтал, ноёдууд Консупын газар үдэш орой хүрэлцэн ирцгээв. Тэдний саадсан явдап нь гарын үсэг зурах сайн өдрийг сонгосон мэргэчийн төлөг буулгасан явдал байжээ. Энэ өдөр сайн өдөр байсан тухай ноёдууд сэтгэп хангапуун надад өгүупж байв. Бид шууд п текстийг нийлүүпэн уншиж, гарын үсэг зурах үйл явцаа эхэлцгээв. Ийм үйл явдлыг анх удаа үзэж буй монгопчууд үунд ихээхэн ач холбогдол өгч хариуцлагатайгаар хандаж байв. Тэд текстийг маш анхаараптай сонсч, өөрсдийн нэрсээ бийрээр зурахдаа маш хичээнгуйлэн хандаж байв.

Дараа нь шампанск задалж, Монголын сайн сайхны төлөө, Орос Монголын найрамдлын төлөө би хундага өргөв. Ноёдууд баярлацгааж, миний гарыг чангаар атгаж, заа хэмээн талархлаа илэрхийлж байв. Сайн ноён бүр жижигхэн үг хэлж, харин сангийн сайд Монголчууд Оросыг дайпснаас хойш энэ үйл явдал бол Монгол Оросын хооронд шууд харилцаа тогтоож буй анхны апхам хэмээн ёжлон тэмдэглэж байв. Одоо бол Монгопчууд оорийн орны хувь заяаны төлөө сэттэл амар байж болно, учир нь Орос орон, цагаан баатар буюу цагаан хаан түүнийг хэнд өгехгуй.

Бидний ярианы үеэр ноёдууд тэдний эргэлзээ сүүпчийн момент хүртэл үргэлжилж, харин Богд хааны өөрийнх нь шаардснаар хэлэлцээрт гарын үсэг зурахаар шийдвэрлэснээ хэлж байв. Учир нь саяхан Бээжингээс ирсэн Парсоны ярианаас эргэлзээ төрж эхэпсэн байжээ. Гарал уүспээрээ норвег Парсон нь америкийн библийн нийгэмпэгийн төлөөлөгч бөгөөд Хурээнд нийгмийн ажлаар 
ирсэн хэмээвч үнэн хэрэг дээрээ Орос упстай хийж буй хэлэлцээрийг таспахыг монголчуудад ятгахаар Бээжингийн засгийн газраас томилогдсон байв.Гэвч монгопчууд түүний бүх саналыг үгүйсгэж, Орос упстай хэлэлцээр байгуулсаны дараа п Хятадтай тэгш Харилцааны үндсэн дээр хэлэлцээр байгуулахад болно Хэмээн мэдэгдсэн байна ${ }^{19 "}$ гэжээ.

Орос Монголын хооронд гэрээ байгуупсны маргааш нь Оросын консугын газар Ханд ван ирж, Хэлэлшээр байгуупсантай холбогдуулан Богд хаанаас баяр хүргэснийг уламжилсан байна. Упмаар Олноо өргөгдсөний хоёрдугаар он өвлийн тэргүүн сарын 16-ны өдөр Монгол улсын Богд хаан зарлиг буулгаж, Орос упсын хаан эзний засгийн газраас гаргасан бүрэн эрх барих сайд И.Я.Коростовецэд Чин вангийн Эрдэний Очир одон шагнан хүртээсэн буй. ${ }^{20}$

Мөн хэсэг хугацааны дараа Оросын Гадаад хэргийн яамнаас Коростовецэд чахилгаан ирсэн бөгөөд түүнд Монголын Засгийн газартай байгуулсан хэпэлцээрийн тухай Эзэн хаандаа айлтгаж, Эзэн хаан нь уг илтгэл дээр өөрийн гараар "Коростовецэд миний талархлыг илэрхийлж байна. Эзэн хааны ивээлийг хүлээн авна уу" хэмээн бичсэн байна.

\section{2 оны Найрамдлын гэрээ байгуулсны дараах үе}

Орос Монголын хооронд Найрамдлын гэрээ байгуулснаас хойш гурав хоногийн дараа Оросын гадаад Яамны сайд Сазонов эл гэрээний талаар Хятадын засгийн газарт мэдээлэхийг албан ёсоор өөрийн элчин сайд Крупенскийд үурэг болголоо. Эп үүргийн дагуу Бээжинд Оросын элчин Крупенский Хятадын Гадаад явдлын яамны сайдад 1912 оны 10 дугаар сарын 26-нд уламжлахад, Хятадын Гадаад яамны сайд "Орос улс Монголын засгийн газрыг хүпээн зөвшөөрчихлөө" шүу дээ "харин Дундад Иргэн упсыг хүпээн зөвшөөрөөгүй $~$ байгаа шүү" хэмээн сануупсан байдаг. ${ }^{21}$ Энэ боп Орос упсын засгийн газраас Монгол улсыг хүлээн зөвшөорсний үндсэн дээр 1912 онд Найрамдлын гэрээ, худапдааны протокол байгуупсан хэмээн дэлхийн улс орнууд ойлгож байсныг илттэж буй хэрэг юм.

Үүнээс хэдхэн хоногийн дараа Хятадын Гадаад яамны сайд Санкт Петербургт айлчипж, Оросын Гадаад яамны сайд пугаа уулзан, Хятад улс Монгол Оросын хооронд байгуулсан гэрээг хүлээн зөвшөөрөөгүй гэдгээ мэдэгдсэн байна. Үүний хариуд Сазонов тайлбарлахдаа: Орос улс Монголын тусгаар тогтнолыг бүрэн гүйцэд зөвшөөрөөгүй юм, гэхдээ бид Хятадыг гурван улсын гэрээнд оруупан хятадын сюзеренитетийг хүпээн зөвшөөрч болох юм гэж мэдэгдсэн байна. ${ }^{22}$

Хятадын засгийн газар Хяталын нэгэн хэсэг болсон Монголтой байгуупсан аливаа гэрээг хүпээн зөвшөөрөхөөс эрс татгапзаж байгаагаа илэрхийлж, Монголын тухай апиваа асуудлаар Хятадын төв засгийн газартай гэрээ байгуулахыг сануупсан байна. Чингэхдээ Хятадын засгийн газар Оросын засгийн газраас эхпээд Монгоптой байгуупсан гэрээгээ цушлахыг шаардаад үүний дараа бид танайтай эл асуудпаар хэлэлцээр хийхэд бэлэн байх болно 
хэмээн мэдэгдсэн байна. 1912 оны 11 дүгээр сарын 19-нд Хятадын сайд Санкт Петербургт Оросын гадаад яамны сайд пугаа уулзаж, Хүрээтэй байгуулсан гэрээгээ чушпахыг бас дахин гуйсан байна. Гэвч эл бухэнд Сазонов, Крупенский хоёуп "Хятадын санал дэндүү оройтож ирлээ" хэмээн хариулсан байдаг. ${ }^{23}$

Оросын Гадаад Яамны сайд Сазонов Монгол Оросын хооронд байгуупсан гэрээнийхээ тапд ийнхуу баттай зогссон нь Оросын засгийн газар Монгол улс, түуний тусгаар тогтнолыг тодорхой хэмжээгээр дэмжсэний ипэрхийлэл мөн. Нөгөө талаас, Хятадын засгийн газар удаа дараа Орос упсаас Монголтой байгуупсан гэрээгээ цуцлахыг шаардаж, гуйж байсан явдап бол Монголын тусгаар тогтнол эргэлт буцалтгүй замд орж байсныг илтгэсэн хэрэг юм. Харин Монгол Улс Орос улсын хооронд гэрээ байгуулагдсанд Хятадын Засгийн газар Гадаад яамны сайдаа бурууптан албан тушаалаас нь огцруупсан бипээ.

1912 оны 11 дүгээр сарын 3-ны өдөр Оростой найрамдлын гэрээ байгуулснаас хойш үеийн Монгол нь бие даасан улс байсан юм, учир нь хоёр орны харипцаа Хятадаар дамжих бус шууд явагдаж байсан бипээ хэмээн Вопосович тэмдэгпэсэн байна. ${ }^{24}$ Тухайн уей̆н Оросын хэвпэлуүд энэхүу гэрээ бол улс биш байсан бол байгуулагдахгуй байсан, нэгэнт байгуупагдсан болохоор Монголыг сюзеренитет болгохын эсрэг байгуулсан гэрээ болжк таарна хэмээн бичиж байжээ. Түүгээр ч үл барам 1912 оны Орос Монголын хооронд байгуупсан гэрээгээр Монгоп упсын нэрийг Гадаад Монгол гэж бус Монгол хэмээн бичиж байхаар Орос упс баталгаажуупсан юм хэмээн Петер Тан бичжээ. ${ }^{25}$ Харин газар нутгийн тухайд ямар нэгэн зүйл эл гэрээнд тусгагдаагүй юм Хэмээн тэрээр бичжээ.

Орос Монголын хооронд байгуупсан гэрээг гадаадын ажигпагчид янз бурээр тайлбарлаж байсан байна. "Орос улс ийнхуү гэрээ байгуулснаар шинэ улс байгуулагдахад тус дэм болпоо" гэх буюу эсвэл “Монгол нь Хятадаас салан тусгаарлаж эрх чөлөөтэй болсноор Оросын колони болчихгүй” хэмээн бичиж байжээ. ${ }^{26}$

Оросын эзэнт гүрэн Богд хаант Монгоп упс хоёр хоорондоо Гэрээ байгуулж, баримт бичгүүд солилцсонооор Монголд эзлэх Оросын нөлөө ихсэх болсон нь Орос, Дундад Иргэн упсын хүчний харьцаанд урьд байснаас нилээд өөрчпөлт орж, улмаар хоёр тал монголын асуудпаар хэлэлцээр хийх хэмжээний асуудал болсон байна. Энэ нь хятадууд Монголыг урьдын адил дангаар эзэрхэх гэсэн Хятадын байр сууринаас хальж, Монголын асуудлыг Оростой ярилцах болсон нь монголчуудын хувьд багагүй дэвшил болсон хэмээн үзүүштэй. Нөгөө талаар Орос Монголыг хэлэлцээр хийх эрх бүхий этгээд хэмээн үзсэн нь Монгол өөрийн тусгаар тогтнолын төлөө асуудапдаа өөрийн санапаа оруупж, түүнийхээ төлөө тэмцэх боломжоор хангагдаж эхэлсэн опопт байлаа. Энэ бол Богд хаант Монголын упсын төрийн удирдагчдын асар их ухаан, хүчин чармайлтын үр дүн хэмээн үзмээр санагдана.

Орос улс Орос-Монголын 1912 оны гэрээгээр олж авсан өорийн давуу талуудыг хэвээр хадгалах нөхшөлд Монголын асуудлаар Хятадтай тохирольоход 
бэлэн байсан билээ. Орос Монголын найрамдлын гэрээнд 1912 оны 11 дүгээр сарын 3-нд Хурээнд гарын үсэг зурсаны дараахан энэхуу баримт бичгийн тухай Оросын Гадаад Явдлын яамнаас Англи, Франц, Япон зэрэг орнуудын элчин сайд нарт албан ёсоор мэдээлэл хийж тайлбарлахдаа, сайд Сазонов: “Хэрэв Хятад упс энэ гэрээний зарчмуудыг хүпээн зөвшоөрвөл түүний зүгээс Монгоптой ямар нэгэн гэрээ хэлэлцээр байгуулж Монголд эзэн эрх (сюзеренитэт) тогтооход татгалзахгүй"27 гэсэн нь Оросын байр суурийг тодорхой ипэрхийлсэн хэрэг байлаа.

Хэдийгээр хятадууд Орос-Монголын 1912 оны найрамдлын гэрээ бичиг болон, харилцан солилцсон бусад баримт бичгүүдийг хууль бус зүйл хэмээн эсэргүуцэж хүпээн зөвшөөрөхөөс татгалзаж байсан хэдий ч Оросууд энэ талаарх өөрийн байр суурийг ягштал баримталж байлаа. Иймээс ч Бээжин дэх Оросын төлөөлөгч Засгийн газрынхаа нэрийн өмнөөс Дундад Улсын Гадаад Явдиын Яамны сайдтай уупзаж, Орос, Монголын хооронд байгуулсан найрамдлын гэрээ болон бусад баримт бичгийн талаар танилцуупж, Орос улсын зүгээс Хүрээний засгийн газрын өмнө хупээсэн үүргийг сануупж, эдгээр баримт бичгийг ДИУаас хүпээн зөвшөөрөхийг шаардсан байна. Чингээд зогссонгүй Оросын зөвлөх Хятадын гадаад явдлын яаманд очиж, 1912 оны 11 дүгээр сард Монголын тап элчингээ томилон Оросын нийспэл - Петербург хотод явуулсан хэмээн худал мэдээлэл хийж байсан нь оросууд Монгол дахь өорийн ашиг сонирхолыг апдахыг хүсэхгүй, упмаар бэхжүүпж, Хятадаар хүпээн зөвшөөрүүпэхийн тулд тэдэнд шахалт үзуүпсэн хэпбэр байв.

Ийнхуү орос, хятадууд өөр хоорондоо хэд хэдэн удаа ноот солилцож, өөр өөрсдийн байр суурийг ипэрхийлсэний эцэст Монголын асуудпаар хэпэпцээр хийхээр харипцан тохиропцжээ.

Орос Монголын 1912 оны гэрээ болон түуний хавсралт Оросын худалдааны эрхийг баталгаажуулсан 1.7 заалт бухий протоколыг эсэргүуцэж байсан хэдий ч Монголын асуудлыг Оростой тохиропцох уүднээс Хятадын засгийн газар эцэст нь тэрхуу Монгол Оросын хооронд байгуупсан худапдааны протоколыг хүпээн зөвшөөрсөн юм. Албан ёсоор 1913 оны Орос Хятадын тунхагийн дөрөвдүгээр заалтад энэ тухай өгүупсэн байдаг. Мөн түүнчлэн 1915 оны Хятад, Орос, Монгол гурван улсын гэрээний 21 дүгээр зүйлд эл асуудлыг баталгаажуупсан юм. Энэ нь 1912 оны Орос Монголын хооронд байгуупсан гэрээ, худапдааны протокол хүчин төгөлдөр болохыг тодорхойлсон хэрэг билээ.

Энэхүу найрамдлын гэрээ нь ямар нэгэн зөрчилгүй явагдсан хэмээн үзвэл бодит байдлаас ташаа болох билээ. Оросын талын санап болгосон гэрээний төсөпд "Гадаад Монгоп" хэмээн бичигдсэн байсан бөгөөд Монголын тал үүнийг эс зөвшөөрч, эсэргүушсэн туп “Монгоп" хэмээх нэрийг хэрэглэкээр тогтжээ. Чингэхдээ "Монгоп" хэмээх нэр нь улсьн нэр байж болох ба бас газар нутгйн нэр зааж болох хоёрдмоп утгатайгаaс гадна Ар Монголыг буюу эсвэп нийт Монгол үндэстнийг хамруулан хэрэглэсэн ойлголт бопж болох салаа утгаар уг гэрээний 


\section{орос эхэнд хэрэгпэгасэн байдаг. ${ }^{28}$}

Энэ тохиропцсон ёсоор гэрээний монгоп эхэнд "Упс" гэдэг үг нэмэн "Монгол улс" гэж хэрэглэсэн байдаг билээ. Энэ нь Богд тэргуутэй Монголын төрийн удирдагчид тулгур байгуупагдсан төр нь бусад улс гүрнүүдийн нэгэн адил эрх бүхий бие даасан улс болохыг харуулахын зэрэгцээ Ар Монголын төдий бус нийт монгол үндэстний гап голомт болсон упс гэсэн санаагаар ойлгож, ийм бодлогыг хэрэгжүүпэхийг хичээж байсны илрэл юм. Мөн түүнчлэн “Монголын засгийн газар" Хэмээх нэрийг хэрэгпэснээс гадна хоёр гэрээ байгуупагч этгээд хоёр упсын засгийн газрыг харипшан хүпээн зөвшөөрсөн явдап монгопчуудын хувьд үнэхээр онцгой ач холбогдолтой байсан юм. Мөн гэрээ байгуулах уеэр Монгоп упсын эдиэх эрх хэмжээний тухай асуудал санал зөрөлдсөн асуудпуудын тоонд орж байв. Гэрээний орос эхэнд Оросын тал нэгэнт тогтсон автономит байгууплыг хамгаалахад Оросын эзэн хааны засгийн газар туслах болно гэсэн ахул, монгоп эхэнд автономит байгуупал хэмээх үгийг хэрэгпэхгүйгээр тусгаар тогтнол гэсэн утгаaр ойлгох уг хэрэглэн: "Их Орос упсын эзэн хааны засгийн газраас Монгол улсыг өөртөө тогтнож өөрөө эзэрхэх ёс журам сахихад туспамуй" гэжээ. ${ }^{29}$

Мөн 1912 оны гэрээ Монгопп өөрийн үйп ажилпагаагаa өргөжуүпэн цэцэглуулэх бүрэн эрх чөлөөг оросуудад олгосон юм, чингэснээр «Монголыг

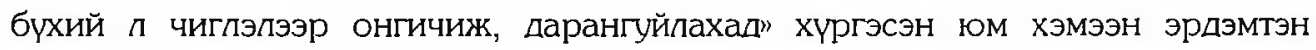
Е.М.Даревская бичжээ. Оросын засгийн газрын дэмжлэгийг албан ёсоор хүпээсэн худапдаа, арипжааныхан апт мөнгө гээд бүхий п бололцоотой бүх ашигт малтмалыг эрж хайх олборлох "Нийгэмлэг", "Нөхөрлөл"-ийг олноор нь Монголд байгуупж, Монгол руу упсын болон хувийн бүхий $п$ барааг оруулан худалдаалж байжээ. Монголын үндэсний банк хүртэл байгуупсан нь буй ажээ. Оросын рубль хятадын мөнгийг бага багаар шахаж эхлэх бопжээ. ${ }^{30}$ Монгол дахь Оросын худапдаа тооны хувьд өсөхийн хэрээр чанарын хувьд ч мөн өсөж байв.

ИйнхуҮ оросууд Монголыг эдийн засгийн хувьд эзлэн түрэмгийлж эхэлсэн энэ үеийг Оросын төрөөс Монголын талаар явуулсан бодпогын хэрэгжилт хэмээн үзуүштэй юм. Мэдээж энэ бүхэнд хил залгаа байдап, удаан жилийн түухийн упбаа, уламжлал, эдийн засгийн харилцан сонирхоп зэрэг нь Орос гүрний зүгээс Монголын талаар түүхийн удаан хугашааны турш тодорхой бодпого баримтпахад хүргэсэн бөгөөд 1911 оны дараа Орос улс бусад их гүрнээс өрсөж, өөрийн боломжийг ашиглан Монголд ашиг сонирхлоо өргөтгөх нь стратегийн хувьд ч чухап байсан юм. Орос Японы гэрээ ёсоор опж авсан өөрийн нөлөөний бүсээ хэн нэгэнд алдах, хэн нэгэнтэй хуваалцах сонирхоп Оросын төрийн эрх баригчдад байгаагуй юм.

1912 онд Орос Монголын хооронд байгуулагдсан эл гэрээ Монголын олон упсын тапбар дээр дахин төр улс болж гарч ирсэний нэгэн илэрхийлэл болсон юм.

И.Я.Коростовецийн гарын үсэг зурсан 1912 оны Монгол- Орос хоёр орны гэрээний учир холбогдлыг Оросын дипломатч Барон Нольде ихэд үнэлж, 
1930 онд ийн бичжээ: “Монгол упсыг байгуупсан нь Оросын эзэнт гүрний дипломат бодлогын томоохон амжилтуудын нэг юм... Энэ сургуупийн тэргүүн эгнээнд дайны өмнө И.Я.Коростовец болон Алс Дорнодын хэлтсийн дарга асан, талийгаач Г.А.Казаков нар зогсож байлаа. Тэрхуу томоохон түүхэн үйл хэргийг хэрэгжүүлэх нэр төр тэдэнд хамтад нь ногдсон байв... Монгол упс бүрэпдэн бий болоход И.Я.Коростовецийн гэрээ шийдвэрлэх үүрэг гуйцэтгэсэн билээ".

Чухамдаa XX зууны эхээр Монгол улс сэргэн мандах үйл явцын эхний шатанд И.Я.Коростовец Монгоп упсын төлөө үнэхээр үпэмж ихийг хийсэн агаад миний бодоход монгопчууд В.И.Пениний үйл хэрэг гэхээсээ ипуу И.Я.Коростовецийн үйл хэргийг Монголын түүх, Монгол, Оросын харилцааны түухэнд илуү тусгавал зохистой юм. Энэ нь түухийн өмнө илуү шударга хэрэг болохсон

И.Я.Коростовец Оросын эзэнт гүрний ашиг сонирхлыг төлөөлж байсан нь эргэлзээгүй боловч Монгол упсын бие даасан байдлыг сахин хамгаапах, улам боловсронгуй болгоход дээрх ашиг сонирхоп асар их уүрэг гүйцэтгэсэн болно. Судлаач Ж.Фритерс И.Коростовечийн талаар өөрийн гэсэн дүгнэлт хийн: "Энэ хүн бол Оросын эзэнт упсын хамгийн чадварлаг диппоматуудын нэг бөгөөд Гадаад Монгопд Оросын бодпогыг идэвхтэй хэрэгжүүлэх үйп хэргийн судсыг гартаа барьж байсан билээ" хэмээн бичсэн байдаг нь тун онож дүгнэсэн Хэмээн үзуүштэй

Хятадад олон жил алба хаах хугацаандаа түуний олж авсан дипломатчийн асар баян туршлагыг нь Дмитрий Абрикосов онцгойпон тэмдэгпэж: "Эпчин (И.Коростовецийг хэлж байна - О.Б.) их онцгой хүн бөгөөд апмаз эрдэнэ мэт чухаг, эрхэм нэр хүндтэй болой" гэжээ. Энэ үг хүнийхээ хувьд тэрээр хэн байсныг тод харуупж буй юм.

И.Я.Коростовец 1912 онд Орос-Монголын Найрамдлын гэрээ байгуулахыг санаачлагчдын нэг мөн гэдэг нь эргэлзээгүйгээс гадна XX зуунд Орос-Монголын харилцааг бэхжүүпэх, цааш хогжүүлэхэд жинтэй хувь нэмэр оруупсан гарамгай диппоматч хэмээн бид үзэж байна.

\section{ДУГНЭПТ}

Энэхуу гэрээ байгуупагдсан нь монгоп хятадын хооронд явж ирсэн урьдын харипцааг тодорхой хэмжээгээр супруулж, монгопчуудын эдийн засаг, амьдрапд оросын оропцоог нэмэгдүүпэх боломж нээсэн билээ.

Хэдийгээр 1912 оны Монгол Оросын найрамдлын гэрээ, худалдааны протоколыг эдийн засгийн асуудлыг голпон шийдвэрлэхэд чиглэсэн хэмээн тодорхойлдог боловч эл гэрээ Монголын хувьд упс төрийн онцгой ач холбогдол агуупсан юм. Орос Монголын хооронд ийм гэрээ байгуулагдсан явдал нь өөрөө монгол хятадын хооронд тогтсон байсан урьдын харипцаа уп бопж, түүнд цэг тавьсан төдийгүй, Шинэ Монгоп улс дэпхийн аль ч улс оронтой эн тэгш харилцах боломж нээж өгсөн юм. ${ }^{31}$ 
Энэ гэрээ нь Монгол улс тусгаар тогтнолоо тунхаглан зарласнаас хойш Монгол улсын олон улсын харипцаанд эзпэх статусыг тодорхойпоход хууль эрхийн анхны бодитой баримт бичиг болсон юм. Энэ гэрээгээр:

1. Монгоп бол эзэн хаантай, Засгийн газартай улс мөн,

2. Монгол нь өөрийн улсын цэрэг байгуупах эрхтэй,

3. Монгол нь "өөртөө тогтнож, өөрөө эзэрхэх" ёс журамтай,

4. Монгоп нь өөрийн нутгаас Хятадын цэрэг ба эрх баригчдыг үлдэн гаргасан бөгөөд дахин өөрийн газарт Хятадын цэрэг ба нүүдпийн иргэдийг ул оруупах эрхтэй,

Монгол нь Хятад болон бусад гадаад улстай хэлэпцээ хийжк өөр гэрээ байгуулах эрх бүхий этгээд мөн гэдгийг Орос улсын Засгийн газар хулээн зөвшөөрч эдгээрийг "алдагдапгүй сахихад" цөм тусална гэж Орос улс өөртөө уурэг авсан байлаа. Гэрээ нь тухайн тодорхой нөхцөлд Монголд нилээд дэвшилттэй алхам болсоныг тэмдэглэх учиртай. Эл хэлэлцээрээр монголчуудын санал болгосон Өвер Монгол, Баргыг Монголд дагаар орох асуудлыг хэлэлцэхээс оросууд эрс татгалзаж, Петербургт Монголын элчин суулгах тухай асуудап мөн татгапзсан хариу авчээ. Өвөр Монголын асуудап нь урьд нь Орос Японы хооронд байгуупсан нууц гэрээгээр нэгэнт шийдэгдсэн байсан бол Оросын нийслэлд Монголын элчин нээх асуудал нь Орос улс нэгэнт Монголын тусгаар тогтнох эрхийг Хятадын харьяаны автономиор хязгаарлах бодолтой байсан учраас татгапзсан санап авсан байна.

Орос улс энэ 1912 оны найрамдпын гэрээгээр Монголын засгийн газрыг, Монголын тусгаар тогтнолыг албан ёсоор хулээсэн бөгөөд кійм ч учраас Монгопыг гэрээ байгуупах эрхтэй хуупь ёсны субьект хэмээн үзсэн хэрэг юм. Орос Монголын хооронд байгуулсан эп гэрээ дэлхий нийтэд зарлагдсан явдап өөрөө Монгол улсын нэрийг "Монгол" хэмээн хүлээн зөвшөөрч тунхагласнаас ялгаагуй хэрэг байлаа. Үүнд мэдээж хятадууд дуртай байгаагүй юм. Ийнхуу дэлхий нийтээр Монгол улс тухайн уед хучирхэг Оросын эзэнт улстай гэрээ байгуулсан нь Монголынхоо тусгаар тогтнолын төлөө тэмцлээ үргэлжлуулэн явуулахад ихээхэн дөхөм үзуупсэн явдал байлаа.

\section{ЭШЛЭЛ, ЗУҮПТ}

1 Үндэсний төв архив фр.4, д.1, х.н.136

2 Н.Магсаржав Монгол Улсын шинэ түүх, УБ., Сүхбаатар хэвлэх үйлдвэр, 1994, 12 дахь тап

3 Н.Магсаржав Монгол Улсын шинэ түух, УБ., Сүхбаатар хэвлэх үйлдвэр, 1994, 12 дахь тал

4 О.Батсайхан Монголын сүүпчийн эзэн хаан VIII Богд ЖКавзандамба хутагт: Амьдрал ба домог, УБ., 2011 он

5 И.Майский Современная Монгопия Ир.,1921г, с.330-331

6 Бепов Е.А. Как возникли тройственные русско-китайско-монгольские переговоры в Кяхте в 1914 г. Китайская традиционная культура и проблемы 
модернизации Часть 1, М.,1994.,с.176

7 Международные отношения в эпоху империапизма Документы из архивов царского и временного правительств (1878-1917) М-Л.1931, серия 2, r. 20, ч. 2, с. 7

${ }^{8}$ Монголын ард түмний 1911 оны үндэсний эрх чөлөө, тусгаар тогтнолын төпөө тэмцэл Баримт бичгийн эмхтгэл., 1900-1914. УБ., 1982, 170 дахь тап

9 Сборник диппоматических документов по Монгольскому вопросу Спб.1914.,с.1-2,

${ }^{10}$ Сборник диппоматических документов по монголскому вопросу. СпБ, 1914, c. 1

11 (Э.Д.Гримм Сборник документов по монгольскому вопросу ...T. 169,180$)$

12 Мөн тэнд

13 "Международные отношения..., сер. 2, т. 18., часть 1., с. 227

14 Л.Жамсран Диссертаци., х.82

${ }_{15}$ Монголын ард түлний 1911 оны үндэсний эрх чөлөө, тусгаар тогтнолын төлөө тэмцэп Баримт бичгийн эмхтгэл . 1900-1914, УБ.,1982он, 174-175 дах тал, Гримм Э. Сборник договоров и других документог по истории международных отношений на Дальнем Востоке (1842-1925) М., 1925он, c. $181-183$

${ }^{16}$ И.Я.Коростовец Монгопд өнгөрүупсэн есөн сар Монгоп дахь Оросын Бүрэн эрхт төлөөлөгчийн өдрийн тэмдэглэл 1912 оны 8 сараас 1913 оны 5 сар, Эмхттэгч О.Батсайхан, Хянан боловсруупсан О.Батсайхан, О.Бакич, Наками Татсуо, УБ.,2010 он

17 И.Я.Коростовец От Чингис хана До Советской республики УБ. , 2004 г. C. 211

г. С. 212

${ }^{18}$ И.Я.Коростовец От Чингис хана До Советской республи:ки УБ. , 2004

${ }^{19}$ И.Я.Коростовец От Чингис хана До Советской респубпики УБ., 2004 г. C.234-235

${ }^{20}$ Үндэсний төв аркив ф.А3, т.1, х.н.27, х.1-5

(Сборник дипломатических документов по Мон. Вопросу 23 авг. 1912г - 2 нояб. 1913г. С.Петербург, 1914, с.32)

${ }^{21}$ Peter S.H. Tang Russian and Soviet policy in Manchuria and outer Mongolia 1911- 1931 Duke university press Durham, North Carolina, 1959 p.314

${ }_{22}$ Мөн тэна р.315

23 М.Вопосович Россия и Монголия - Вестник Азии Ио 31-32, 1914 , c. 42

${ }^{24}$ Peter S.H. Tang Fussian and Soviet policy in Manchuria and outer Mongolia 1911- 1931 Duke university press Durham, North Carolina, 1959 p.313

${ }^{25}$ Peter S.H. Tang Russian and Soviet policy in Manchuria and outer Mongolia 1911- 1931 Duke university press Durham, North Carolina, 1959 p.316 
${ }^{26}$ Б.Санжмятав Гурван улсын Хиагтын гэрээний тухай түухэн үнэн., УБ., 1991., 7 дахь тал

27 Сборник договоров России с другими государствами 1856-1917, М, 1952., с.411

28 Үндэсний төв архив ф. 1, д.1, х.н.74

${ }^{29}$ Н.Е.Единархова Русские в Монголии: Основные этапи и направления деятепьности в 1861 -1919 гг.- Материапы конференции "Россия и Монгопия в многополярном мире" \Часть 1, вып 2, Иркутск., 2000, с. 62

${ }^{30}$ O.Батсайхан Монголын тусгаар тогтнол ба Хятад, Орос, Монгол гурван упсын 1915 оны Хиагтын гэрээ (1911 -1916) УБ., 2002 он, 259 дэх тап

${ }^{31}$ Үндэсний төв архив, ф. А4. Т.1.х.н. 656 